[Humanics]

\title{
Origins of Molecular Biology in Japan
}

\author{
Masayuki OBAYASHI \\ Division of Humanics, School of Medicine, University of Occupational and \\ Environmental Health, Japan. Kitakyushu 807, Japan
}

Abstract: The purpose of this paper is to discuss the origins of molecular biology in Japan. Japanese molecular biology does not have a long history since it started only after World War II. Especially, molecular genetics which uses "bacteriophage" had hardly been studied before the war and only a few scientists were interested in it immediately after the war. This is one of the origins of molecular biology in Japan. But there are other origins, one of which is the group formed by biologists, biochemists and physicists interested in nucleic acids. This group also started just after the war. Still another origin is the group of enzymologists. Enzymology was one of the main subjects of biochemistry from before the war. In Japan, biochemistry developed in conjunction with the medical and agricultural sciences from the pre-war era. These played an important role in introducing molecular biology from Europe and the United States after the war. A historical study of the development of molecular biology in Japan, comparing it with the history of molecular biology in Europe and the United States, should contribute to the elucidation of the features of the history of molecular biology in Japan.

Key words: history of biology, molecular biology, biochemistry, nucleic acids, bacteriophage.

(Received 13 Februay 1986)

\section{Introduction}

This study will make clear the history of molecular biology in Japan, especially its origins.

First of all, I must answer the question, "What is molecular biology in Japan?". I am sure many of you would find it difficult to answer this question. My definition is that molecular biology is a biological science studying microbiological genetics by using bacteriophage (in the following sentences I use "phage" for bacteriophage) and regarding nucleic acids as the material subject of genes. Because this definition can be applied to molecular biology in Europe and the United States, I think, it is useful to compare the history of molecular biology in Japan with that of molecular biology in Europe and the United States (Olby, 1974; Portugal \& Cohen, 1977; Judson, 1979).

This paper was presented at the XVII International Congress of History of Science (University of California, Berkeley, 1985) 


\section{When did molecular biology start in Japan?}

In Japan the genetical study on phage and nucleic acids was hardly known before World War II. During the war, it was very difficult for Japanese scientists to gather information from foreign countries. Information on nucleic acids, phage and microbiological genetics were introduced into the Japanese university libraries after the war. And just after the war, G. H. Q. (American General Headquarters) established the C. I. E. (Civil Information and Education) library in Tokyo. Many Japanese scientists visited this library to study foreign biological literature (Nojima, 1956; Shibatani, 1969; Watanabe, 1978). In the early days after the war, Japanese scientists were influenced greatly by the material in this library. Among these scientists, there were a few scientists interested in nucleic acids. They began to study phage and nucleic acids together.

\section{The origins of molecular biology in Japan}

Japanese molecular biology has three origins. The first origin is the molecular geneticists who used phage. In Japan, before World War II, the study of virus was connected with infectious diseases, and this tradition continued after the war (Fukumi, 1956). Among the Japanese geneticists there were some who used silkworms to investigate the relationship of genes to metabolism (Ishidate, 1980). Therefore, some scientists who were interested in phage after the war began to research means to treat virus, for example ultracentrifuge (Watanabe, 1978). Also, a small group began to use phage in order to study genetical phenomena. The leader of this group was Itaru Watanabe who received strains of phage from Max Delbrück (Watanabe, 1978). The Japanese scientists who had received phage began their study with no experience in the use of this special organism, and also at that time some biochemists (for example Masami Suda) did not think that reproduction was the primary feature of living things (Akabori et al., 1952). Therefore, the study on reproduction of phage was not directly connected with genetics. Those who were interested in gene replication had few facilities for study. Therefore, first of all, they had to create the necessary facilities, and then study foreign research papers.

The second origin is the group formed by biologists, biochemists and physicists interested in nucleic acids after the war. Of course, before the war, there were some studies on nucleic acids in Japan (Nakamura, 1985), but most of them were interrupted during the war. There was thus a big gap between before and after the war, concerning the study of nucleic acids. Just after the war, a few biologists and physical chemists began to have an interest in nucleic acids, because they noted that there were many papers in the G. I. E. library and the university libraries, concerning the study on nucleic acids. In order to collect materials, they formed a group to survey these papers. The group was called "Kakusan Kenkyu Kai" (Shibatani, 1958, 1969; Watanabe, 1978), in 
Japanese. At the beginning of its activities some of the members were not interested in the role of nucleic acids in genetical phenomena. Their main interests in nucleic acids were connected with metabolism. Therefore, not all of them regarded nucleic acids as the material subject of genes (Shibatani, 1969). And most biologists at that time did not think that genes controlled all genetical phenomena. Some of them thought that genetical phenomena were carried out by metabolism, and that the reproduction was a part of metabolism (Akabori et al., 1952).

The third origin is a group of enzymologists. Compared with the above-mentioned two origins, this origin had continued from the pre-war era (Suda, 1966). After the war, one of the most important studies was the study on adaptive enzymes (Suda, 1950a, 1950b). This study was strongly connected with Jacques Monod's study (Nojima, 1956), but some of the Japanese enzymologists thought that the production of adaptive enzymes was controlled by the changing metabolism. They did not think that there were genes for producing adaptive enzymes (Akabori et al., 1952). However, as they accumulated a basic knowledge of enzymes at the molecular level, their later studies were helpful to understand the information on molecular biology from foreign countries.

\section{The common features of three origins of molecular biology in Japan}

As mentioned above, there were some biological studies at the molecular level in biochemistry and genetics in Japan before the war, but until the mid 1950's, the studies were not successfully continued (Nojima, 1956; Shibatani, 1969; Nakamura, 1970). In addition, in the early days after the war, some Japanese biologists (particularly biochemists) treated genetical phenomena as metabolical reaction, as they did not think that a substantial unit such as genes would control all genetical phenomena. I think that they were influenced by the theory of dynamic equilibrium (Shibatani, 1947, 1969; Fushimi et al., 1951; Akabori et al., 1952; Suda, 1966).

What about molecular biology in Japan? As mentioned above, there were three origins of molecular biology in Japan. In this paper, molecular biology means microbiological genetics and biochemistry, especially when using phage and regarding nucleic acids as the material subject of genes. In this meaning the first feature is that Japanese molecular biology started just after the war without any tradition continuing from before the war. In other words it was a foreign-made discipline.

The second feature is that the Japanese biologists who gathered information from foreign countries knew little about the background of the information, for example Max Delbrück's methodology (Obayashi, 1984). But Japanese biologists gradually acquired a knowledge of molecular biology. After the mid 1950's, molecular biological studies increased in Japan (Nakamura, 1970). Gradually, Japanese biologists recognized the methodological arguments of molecular biology. But generally speaking, Japanese molecular biologists could not understand the philosophical meaning of the methodology of 
molecular biology, that is to say, reductionism. Thus reductionism became a serious problem for them during the 1970's (Watanabe, 1974).

The third feature is that some of the Japanese biologists were influenced strongly by the theory of dynamic equilibrium in the early days after the war (Shibatani, 1947, 1969; Fushimi et al., 1951; Akabori et al., 1952; Suda, 1966), therefore they did not have a mechanistic view of life. Also at that time, almost all Japanese geneticists were involved in the controversy concerning Lysenkoism, and this controversy continued until about the middle of the 1950's (Nakamura, 1967).

\section{The role of physicists in the early days of molecular biology}

Finally, how can we compare the history of molecular biology in Japan with that of molecular biology in Europe and the United States?

About the origins of molecular biology in Europe and the United States, Gunther Stent wrote the "classical" description (Stent, 1968). In his description, the role of physicists, for example Niels Bohr, Max Delbrück and Erwin Schrödinger, was emphasized particularly in the rise of molecular biology in Europe and the United States. Compared with this description, in the early days after the war in Japan, the physicists' arguments on the biological phenomena were rarely connected with reproduction and heredity. A few physicists had an interest în Schrödinger's book; "What is Life?" (Schrödinger, 1944), but it did not influence deeply Japanese biologists (Akabori et al., 1952). The physicists who were interested in biology were concerned with the physical phenomena in organisms, for example, the problems of properties of matter in organisms (Oka, 1967).

\section{Conclusion}

Therefore, I think, Japanese molecular biology emerged mainly from biochemistry. And I also think that it is not always necessary for the advancement of molecular biology to understand the original methodology and philosophical arguments of molecular biology. In Japan the rise of molecular biology did not mean a revolution in biology, but some change of methodology in biochemistry might have happened. Japanese biochemists perhaps understood that molecular biology helped them to see the functions of organisms at the molecular level more clearly than before. In Japan we say that science is connected with technology. The success of biotechnology in Japan might force Japanese scientists to change their methodology and their view of life. However, up until now we have hardly heard any arguments regarding the methodology of molecular biology and biotechnology of the future. 


\section{References}

Akabori, S., Ashida, J., Okunuki, K., et al. (1952): Seimei no kagaku (Symposium). Kagaku (Chemistry), 7 (1): $32-40$.

Fukumi, H. (1956): Nihon no uirusugaku no sengo 10 nen. Shizen, 11 (5): 72.

Fushimi, K., Egami, F., Tachibana, T., et al. (1951): Kagaku, butsurigaku, seibutsugaku sono chigai to kasanari ni tsuite (Symposium). Kagaku (Chemistry), 6 (6): 39-48.

Ishidate, M. (1980): Hideo Kikkawa's works on eye pigment in Bombyx (1937-1950). Kagakushi Kenkyu, II, 19: 129-139.

Judson, H. F. (1979): The Eighth Day of Creation. Simon \& Shuster, New York. 686 pp.

Nakamura, T. (1967): Ruisenko Ronsou. Misuzushobou, Tokyo. 277 pp.

Nakamura, T. (1970): Seibutsugaku to Shakai. Misuzushobou, Tokyo. pp. 83-134.

Nakamura, T. (1985): Forerunners of molecular genetics in Japan. Kagakushi kenkyu, II, 24: 1-9.

Nojima, T. (1956): Seikagaku. Shizen, 11 (5): 24-33.

Obayashi, M. (1984): The role of complementarity in Delbrück's study of life. Seibutsugakushi Kenkyu, No. $44: 17-34$.

Oka, S. (1967): Koubunshibutsurikenkyu sousou no koro. Ouyoubutsuri, 36 (12): 74-78.

Olby, R. (1974): The Path to the Double Helix. The Macmillan Press, London. 510 pp.

Portugal, F. H. \& Cohen, J. S. (1977): A Century of DNA. The MIT Press, Cambridge. 384 pp.

Schrödinger, E. (1944): What is life? In: What is Life? \& Mind and Matter (1980). Cambridge University Press, Cambridge. pp. 1-96.

Shibatani, A. (1947): Rironseibutsugaku - Doutekiheikouron -. Nihonkagakusha, Kyoto. 196 pp.

Shibatani, A. (1958): Japanese investigations on nucleic acids. Nature, 181: 1511-1513.

Shibatani, A. (1969): Shougen. In: Kagakusha wa Kawatta ka (1981), Asahi Shuppansha, Tokyo. pp. $115-142$.

Stent, G. (1968): That was molecular biology that was. Science, 160: 390-395.

Suda, M. (1950a): Tekioukouso (I). Shizen, 5 (6): 32-42.

Suda, M. (1950b): Tekioukouso (II). Shizen, 5 (7): 18-28.

Suda, M. (1966): Osaka no seikagaku no nagare no naka de. Shizen, 21 (8): 32-36.

Watanabe, I. (1974): Raifusaiensu to Ningen. Nihonkeizaishinbunsha, Tokyo. 206 pp.

Watanabe, I. (1978): Seimei no Rasenkaidan. Bungeishunju K. K., Tokyo. pp. 43-90. 


\section{日本における分子生物学の起源}

大 林 雅 之

産業医科大学医学概論研究室

要旨：本論文の目的は日本に扔ける分子生物学の起源に関して若干の考察を試みることである. 日本に扔ける分子生物学の進展は長い歴史を持つものではなく，その起源は第二次世界

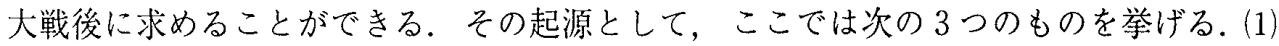
「バクテリオファージ」を扱う分子遺伝学の開始，(2) 核酸に興味を持った生物学者, 生化 学者，そして物理学者らによる研究会の結成，(3) 戦前からの伝統を持つ醳素化学研究の

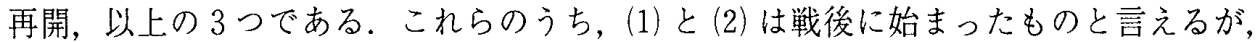
(3)については，そこで挙げた酵素化学というものが，日本では戦前から生化学の主要研 究課題の1つであったことに注意しなければならない，日本に扔いて生化学は，戦前から 医学や農学に伝統を保持して発達してきたものである，それ故に，これらの分野が戦後に おいて，欧米から分子生物学を導入する上で重要な役割を担ったと言える。このような日 本に扔ける分子生物学と生化学との関係についての研究は，分子生物学の起源に扔ける物 理学者の役割を強調する欧米の分子生物学史研究と比較すると, 日本の分子生物学の進展 における特徴を明らかにする上で有効であると言えよう。

J. UOEH (産業医大誌)， 8 (2): 251-256 (1986) 